\title{
Linguistic game plays (version for Hindi)
}

\author{
Indira A. Gazieva, Anna Zakharova, Ksenia Isaeva
}

RUSSIAN STATE UNIVERSITY FOR THE HUMANITIES (MOSCOW)

indira_gazieva@mail.ru

\begin{abstract}
This article describes how teachers of Hindi language can diversify their lessons teaching language for one or twoyear students. The research concerns the usage of linguistic game Sudoku on Hindi lessons. The article from which we have made a start is called "Learning to Hypothesize with Confidence through Sudoku Game Play". It was written by Y.L.Teresa Ting, a teacher of the University of Calabria (Italy). The Hindi version of this game aims to stimulate interest among students in the study of complex grammar of Hindi language, especially mastering the skills for using postpositions, which are not in their native language. This game is suitable both for self-study student, and to conduct a linguistic group.
\end{abstract}

The teaching oriental language for Russian students is very interesting process but includes many difficulties and depends not only by students but teachers and the language environment too. In our opinion, teaching Russian students any orient language should be a captivating game. It is necessary to compose a teaching material so that teacher and students could turn their attention from one exercise to another. Educational process should join a game element. Experienced teachers note that mechanical repetition of new words does not lead to stable memorization but only repetition based on associative thinking and visual accompaniment produces a good effect. Such teaching materials as riddle, joke, painting of topic-related assignments, dewing up the cards and tables are convenient forms of recreation and new assignments. Collecting Hindi text-book for students at Russian State University for the Humanities (Moscow) the visual aspect with use of associative thinking, exercises on attentiveness and variants of developing games are also used.

This article deals with a linguistic game which involves both the first and the second category: it is quite fit for a single student and it can be well played both in a small and large group. The article from which we have made a start is called "Learning to Hypothesize with Confidence through Sudoku Game Play". It was written by Y.L. Teresa Ting, a teacher 
of the University of Calabria (Italy). The author gave a scenario - one can play Sudoku in the language group mastering the skills for using modal verbs. The students are divided into teams and together agreeing or disagreeing with versions answering the teacher's questions and one another's are using phrases from a hand-out which had been dealt with earlier. In other words the stress was not made on the game itself, not its conception but mainly on the discussion. We have found the other way and the accentuation was made on the game as it is.

\section{Hindi linguistic games in the process of activating vocabulary}

The advantage of the linguistic games in the process of teaching foreign languages is obvious: it allows in a natural game environment to train language skills of the students, activates a prompt reaction and helps eliminate a language barrier. It refers to group or team games. There exist a host of varieties of rebuses, riddles, crosswords, puzzles etc for individual work without any intention of the contact with class-mates.

\section{The game conception:}

Let's recall the way the classic Sudoku is played. The rules of the game are simple:

$>$ first, the most important numbers of Sudoku is 9:

$>$ the second, the field contains 9 section: 3x3 squares separated by straight lines;

$>$ thus, each section consists of 9 squares, 3 columns and 3 lines;

$>$ on the whole, the field is made up of 81 squares -9 horizontally and 9 vertically;

$>$ it is necessary to fill in squares with digits from 1 to 9. In doing so a number must be only once in the section, once horizontally and once vertically.

We are suggesting a modified version of the Sudoku game intended for the students who start to learn Hindi language. One of the main problems arising at the beginning of teaching Hindi is the introduction of a great relating numbers of postpositions into the active vocabulary. We have made a game for the students who will easily and quickly master postpositions forming the basis of the Hindi grammar.

Postpositions are the prepositions in Russian language but in Hindi they stand not in front of the depending word but after it. There are simple and compound postpositions in Hindi. The simple one consists of a word and they are 5: ko - to, se - from, men - in, par - on, at, tak - up to, as far as, until.

The compound one involves 2 words and more. We use in this game the simpliest and frequently postpositions: ke lie - for, ke paas - close, near 
to, men se - from amongst, out of. All these are very common in speech in various contexts, stable combinations, proverbs.

\section{Game rule}

Compared to the classical Sudoku our game is as follows: the students must arrange 9 postpositions (not the digits) in the field of 81 squares (the square is 9x9):

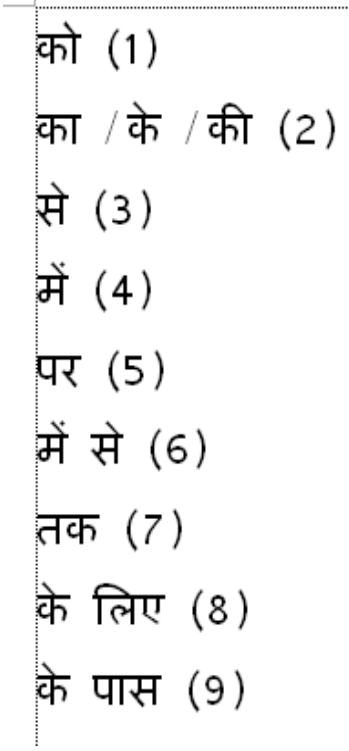

(1) ko to(etc.)

(2) kaa $\backslash k e \backslash k i i \quad$ (postposition expressing possession)

(3) se from

(4) men in

(5) par on, at

(6) men se from amongst, out of

(7) tak up to, as far as, until

(8) ke lie for

(9) ke paas close, near to

In our version the main rules of the Sudoku game are preserved which are to be strictly observed by the participants. Here they are:

$>$ in any of the squares $3 \times 3$ postpositions can not be repeated:

$>$ postpositions can not be repeated both in corresponding horizontal and vertical rows either:

All the squares numbered in such a way that the example of the given specific square can be calculated according to its "coordinates" (the digits are arranged vertically and the letters of Hindi alphabet are arranged horizontally) :

Grid 1:

1क:

(1ka) 


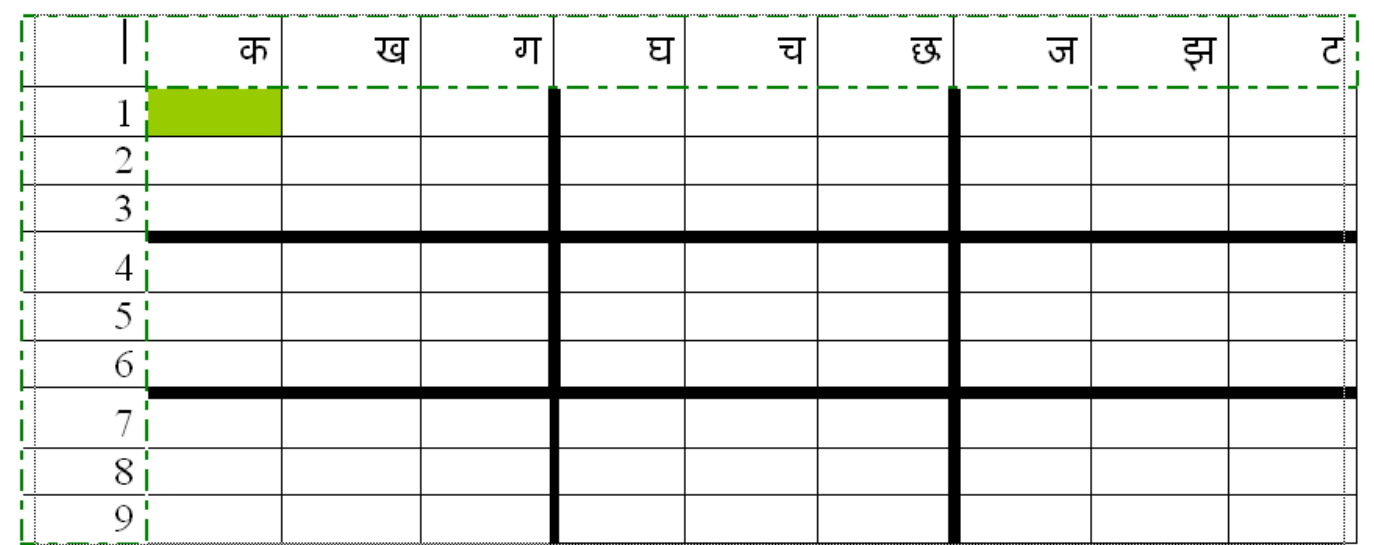

What remains to the student is to look through the examples and if he knows what postposition must be at the place of dots in the given specific sentence, he must insert it in the corresponding square in the field. The peculiar criterion for testing the answers is just the rules: if two similar postpositions happen to be in one row that means we need to check our answers again. In addition id a student is not able to find out all the getting in of the postpositions in the examples he/she has got an opportunity "to start from the contraries" and try to solve logically on which square which preposition can be best inserted. Then he/she checks whether the answer fits the corresponding example (the text-book can be used or ask the teacher). As a result a student receives the completed field of answers:

Grid 2:

\begin{tabular}{|c|c|c|c|c|c|c|c|c|c|}
\hline & क & ख & ग & घ & च & छ & ज & झ & $\tau$ \\
\hline 1 & से & मे & को & के पास & में से & के लिए & $\begin{array}{c}\text { का / के } / \\
\text { की }\end{array}$ & तक & पर \\
\hline 2 & के लिए & के पास & तक & पर & $\begin{array}{c}\text { का /के / } \\
\text { की }\end{array}$ & को & से & में से & में \\
\hline 3 & $\begin{array}{l}\text { का /के / } \\
\text { की }\end{array}$ & में से & पर & में & तक & से & को & के पास & के लिए \\
\hline 4 & के पास & के लिए & में & $\begin{array}{c}\text { का / के / } \\
\text { की }\end{array}$ & से & पर & में से & को & तक \\
\hline 5 & पर & तक & में से & के लिए & को & के पास & में & $\begin{array}{c}\text { का } / \text { के } / \\
\text { की }\end{array}$ & से \\
\hline 6 & को & $\begin{array}{c}\text { का /के } / \\
\text { की }\end{array}$ & से & तक & में & में से & पर & के लिए & के पास \\
\hline 7 & तक & को & के पास & में से & पर & में & के लिए & से & $\begin{array}{c}\text { का / के / } \\
\text { की }\end{array}$ \\
\hline 8 & में & से & के लिए & को & के पास & $\begin{array}{c}\text { का / के / } \\
\text { की }\end{array}$ & तक & पर & में से \\
\hline 9 & कें से & पर & $\begin{array}{l}\text { का } / \text { के / } \\
\text { की }\end{array}$ & से & के लिए & तक & के पास & में & को \\
\hline
\end{tabular}


The use of this advantage of the game (we mean the opportunities for the students that they can calculate on the basis of the rules the correct answer without knowing it) is to enable the teacher during the preparation of materials for this game to include the examples of various levels of complexity in the tasks. For examples, the most obvious meaning of the preposition में men - "in, inside of smth." The students will easily find out the contexts and transfer in the grid. The great complexity can be examples when the postposition में men - "in, inside of smth." is not used in its first obvious meaning: हिंदी में बोलिए। Hindii men bolie - "Speak Hindi". This example illustrates the rule according to which the expression "in some language is translated into Hindi" literally like "in some (any) language". Let's talk about the postposition पर par with his first meaning "on something", but it also forms the part of the stable and a very common expression आम तौर पर _ aam taor par "usually, as usual". So if a student is not aware of it he logically, solving a puzzle, will start solving it from other side. He will calculate that in a certain square there must be just this postposition and later during the checking of the solution the teacher will just accentuate the attention of the students on this non-trivial usage of postpositions.

More over the game can be undoubtedly conducted in the group for consolidation of the material passed: on this case the examples are taken from the text-book in use (the way ahs been done in our pattern using selfstudy books by Rupert Snell). Should we divide the group into two teams then there is a sense of trying to play the set time (the students are well aware of the details of the task). But our game is far from a certain number of participants involved. We have already said that it suits both the individual work and the group one. In the last case it would be of interest to organize a game the way Y.L.Teresa Ting suggested in her article: e.g. hand-outs can be prepared beforehand and the students will find standard phrases for expression of certainly or uncertainly in their guess. For examples,

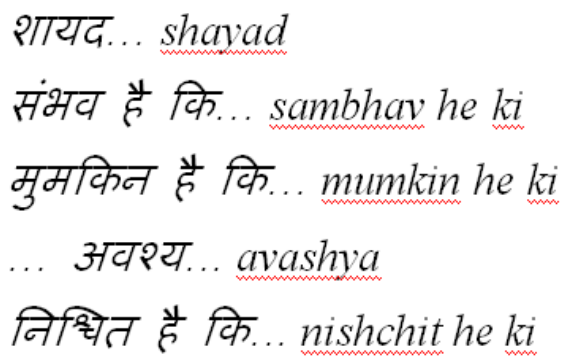


Indira A. Gazieva, Anna Zakharova, Ksenia Isaeva: Linguistic game plays

$$
\begin{aligned}
& \ldots \text { हो / ho } \\
& \ldots \text { होगा/ hoga } \\
& \ldots \text { हो सकता है/ ho sakta he } \\
& \ldots \text { लगता है। // लगता है कि... lagta hel lagta he ki }
\end{aligned}
$$

We demonstrate below how the students can play the Sudocu game on Hindi. The teacher's task includes many Hindi sentences with gaps where they can fill them with appropriate postpositions. The English sentences translate the Hindi ones and demonstrate right equivalents in boldunderlined-italic. The students fill the grid with right postpositions. All answers are given on Grid 2 (cited above). For example:

1क) मैं यहाँ तीन साल ... काम करती हूँ। (से) main yahaan tiin saal ...kaam kartii huun (se) - "I have been working here since three years".

\section{Grid 3:}

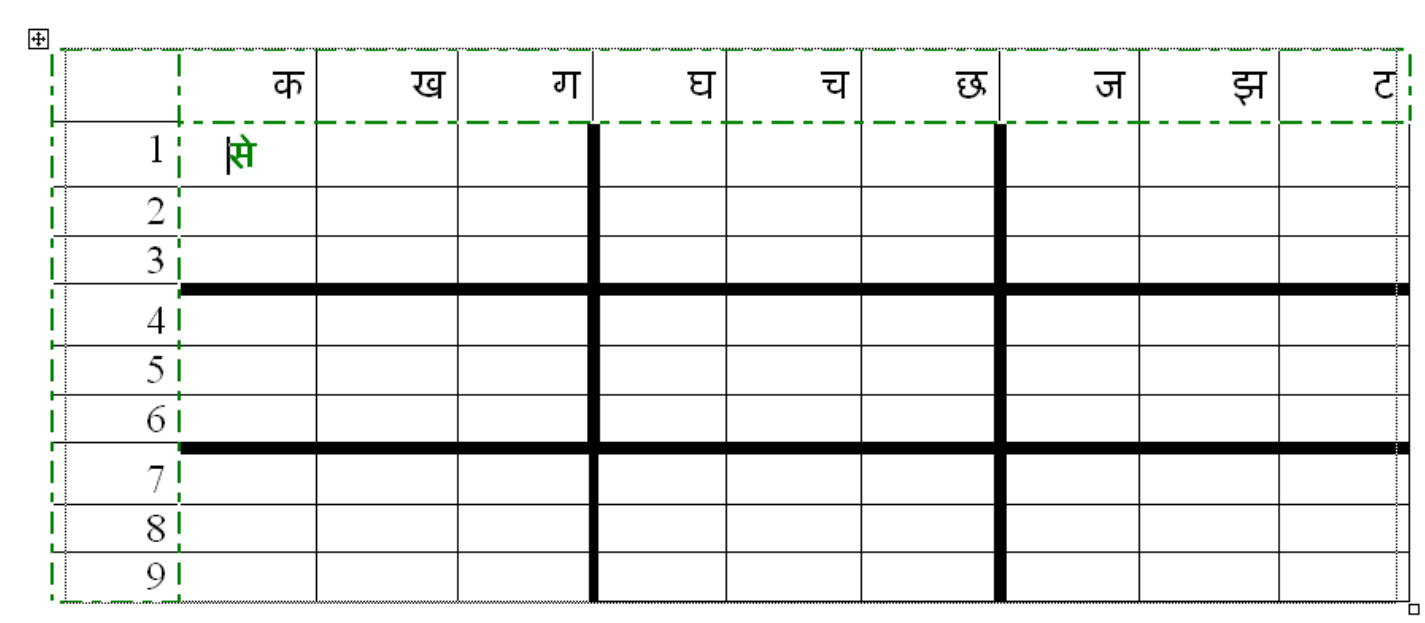


1ट) जमीन ... कुछ पड़ा है। zamiin ... kuchh paraa hei - "Something was laying on the earth".

1ख) घर ... सामान है। Ghar ...saamaan hei - "There is a furniture in the house".

1ग) इस किताब ... रखो। Is kitaab ... rakho! - "Put this book!"

1ज) मनोज इक्कीस साल ... है। Manoj ikkiis saal ... hei-Manoj is twenty one years old.

1घ) कुछ लोगों ... कुछ नहीं है। Kuchh logon ... kuchh nahin hei - "Some people don't have anything".

1झ) वे लोग कल सुबह ... पहुँचेंगे। Ve log kal subah ... pahunchenge - "Those people will arrive till tomorrow".

1च) मैं किताब अलमारी ... लेती हूँ। Mein kitaab almaarii ... letii huun - "I take the book from the bookcase".

1छ.) हमारे ... पहाड का मौसम सब से अच्छा मौसम होता है। Hamaare ... pahaar kaa maosam sab se achchaa maosam hotaa hei - "Mounting weather is the most convenient for us".

2ग) अगस्त के आख़िर ... मैं अपने दोस्त के यहाँ रहूँगा। Agast ke aahir ... mein apne dost ke yahaan rahuunga - "I will stay at my friend's place till the end of August".

2ज) आगरे ... ख़त भेजना। Agre ... hat bhejnaa! - "Send the letters from Agra!"

2छ) उन लोगों ने चोर ... देखा। Un logon ne chor ... dekhaa-Those people have seen the thief".

2च) आप ... कितनी बहिनें हैं? Aap ... kitne bahinen hen? - "How many sisters do you have?"

2घ) हम अपने बच्चों को सड़क ... खेलने नहीं देते। Ham apne bachchon ko sarak ...khelne nahin dete - "We don't allow our children to play on the street".

2ख) मेरे घर ... बहुत बड़ा बाग़ है। Mere ghar ... bahut baraa bag hei -"There is a very big garden near my house".

2झ) वह दराज़ ... बीरियों का पैकेट निकाल रहा है। Vah daraaz ... biiriyon ka peiket nikaal rahaa hei - "He is taking $\underline{\text { of }}$ the drawer the packet of biri".

2क) वे लोग ये चीज़ें उन के लिए बनाते हैं, अपने ... नहीं। Ve log ye chiizen un ke liye banate hein, apne ...nahin - "Those people make these things for those but not for themselves".

2ट) वह अस्पताल ... काम करती है। Ve aspataal ... kaam kartii hei-"She works $\underline{\text { at }}$ the hospital". 
उख) उन ... वह सब से ऊँची है। Un ... vah sab se uunchii hei - "He is the tallest among all people".

उट) वह चपातियाँ मेरे ... लाता है। Vah chapaatiyan mere... laata hei- "He brings the flat cakes for me".

उक) ये उस आदमी ... कपड़े हैं। Ye us aadmi ...kapre hein - "These clothes are of that man".

3ज) दादीजी ... चशमा चाहिए। Daadii jii ...chashmaa chaahiye - "Grandma needs glasses".

3झ) अस्पताल स्कूल ... है। Aspataal skuul ... hei-"The hospital is near the school".

उग) दीवारों ... तस्वीरें हैं। Diivaaron ... tasviiren hein - "There are pictures on the walls".

उघ) परिवार ... पाँच लोग हैं। Parivaar ... paanch $\log$ hein - "There are five people $\underline{\text { in }}$ the family".

3च) हम अक्सर रेलगाड़ी से कलकते ... जाते हैं। Ham aksar reilgaarii se Kalkatte ...jaate hein - We often go to Kolkata by train".

उछ) मैं हर रात को पिंकी ... मिलने जाता हूँ। Mein har raat ko Pinki ... milne jaata hun - "I go to meet with Pinki every night".

4च) मालूम होता है कि संगीता उस ... नफ़रत करती है। Maaluum hotaa hei ki Sangiitaa us ... nafrat kartii hei- "It seems Sangita hates him".

4 छ) आम तौर ... हम बगीचे में घूमते हैं। Aam taor ... ham bagiche men ghuumte hein - "We usuallv go for a walk in the garden".

4ग) छुट्टियों ... उसको अमरीका जाना चाहिए। Chhuttiyon ...usko Amriikaa jaanaa chaahiye - "He should go to America on the holiday".

4ज) मैं डिब्बे ... बक्सा ले रही हूँ। Mein dibbe ... baksaa le rahii huun - "I am taking the suitcase from the compartment".

4ख) उनके पड़ोसी उन ... खाना बनाते हैं। Unke parosii un ... khaanaa banaate hein - "Their neighbors prepare the meal for them".

4घ) तरह तरह ... बीमारियाँ गाँव में फैल रही हैं। Tarah tarah ... biimaariyaan ganv men pheil rahii hein - "A lot of various diseases are spreading in the village".

4ट) मैं छह बजे ... काम खत्म करता हूँ। Mein chhah baje ... kaam hatm kartaa huun - "I finish my work $\underline{\text { until } 4}$ o'clock". 
5ट) वह वहाँ बिल्ली ... बात करता है। Vah vahaan billii ...baat kartaa hei- "He talks with the cat there".

5ज) हिंदी ... "house" को क्या कहते हैं? Hindii ... "house"ko kyaa kehte hein ? "What is the "house" on Hindi ?"

5च ) मनोज ... बाहर जाने दो। Manoj ... baahar jaane do! - "Let's give Manoj to go out".

5ख) चाहता हूँ कि तुम शाम ... चुप रहो ! Chahataa huun ki tum shaam ... chup raho! - "I want you to keep silence in the evening".

5 झ) मीना दस साल ... है। Meena das saal ... hei - "Meena is 10 years old".

5ग) उस ... चोर ने भी कुछ लिया। Us ... chor ne bhii kuch liyaa - "The thief has also taken something from that (place)".

5घ) मैं थैले को ले रहा हूँ ताकि कुछ चीज़ें निकालने ... । Mein theile ko le rahaa huun taaki kuch chiizen nikaalne ... - "I am taking now my purse to take some things out from there".

5छ) पिताजी ... समय नहीं है। Pitaajii ... samay nahin hei - "The father has not any time".

5क) पिताजी अपने बच्चे ... गुस्से हैं। Pitaajii apne bachche ... gusse hein - "The father is very angry $\underline{\text { on }}$ their children".

6छ) इन कमरों ... एक बहुत बड़ा है। In kamron... ek bahut baraa hei- "There is the one biggest room among others".

6झ) अपने ... खाना लीजिए। Apne ...khaana lijiye - "Please take the food for vourself'.

6ग) वह बहुत ध्यान ... नहीं पढ़ता। Vah bahut dhyaan ... nahin parhtaa-He doesn't study attentivelv".

6ज) पेड ... कुछ कच्चे संतरे हैं। Per ... kuchh kachche santre hein - "There are some unripe oranges on the tree".

6घ) मेरा भाई पहली दिसंबर ... घर लौटेगा। Meraa bhaaii pehlii disambar ...ghar laotegaa - "My brother will come back home on the first of December".

6क) समाचार ख़ीदने ... मैं हमेशा बाजार जाता हूँ। Samaachaar hariidne ... mein hameshaa baazaar jaataa hun - "I often go to the market to know news".

6च) हिंदी ... बोलिए। Hindi ...boliye! - "Speak Hindi". 
7 झ) मैं अध्यापक ... पूछता हूँ। Mein adhyaapak ...puuchhtaa huun - "I ask a teacher".

7ट) किसी ... घर में कोई चूहा रहता था। Kisii ... ghar men koii chuuhaa rehtaa thaa - "A rat lived in someone's house".

7 ग) क्या आप ... साइकिल है? Kyaa aap ... saaikil hei? - "Do you have a sycle?"

$7 छ)$ बच्चे बग़ीचे ... खेलते हैं। Bachche bagiiche ... khelte hein - "The children play $\underline{\text { in the garden". }}$

7क) प्रताप अगले हफ़्ते ... दिल्ली से लौटेगा। Prataap agle hafte ... Dillii se laotegaa - "Pratap will return from Delhi till next week".

7घ) इन नगरों ... दिल्ली सब से बड़ी है। In nagaron ... Dillii sab se barii hei"Among these cities Delhi is the biggest one".

7 ज) वह्न दूसरों ... गाती है। Vah duusron ... gaatii hei- "She sings for other people".

7च) राज हमेशा घर ... क्यों रहता है? Raaj hameshaa ghar ... kyon rehtaa hei ?"Why Raj always stay $\underline{a}$ home?"

8ख) संगीता राज ... लम्बी है। Sangiitaa Raaj ...lambii hei-"Sangeeta is taller than Raj".

8च) मैं डाक्टर ... जाता हूँ। Mein daaktar ... jaataa huun - "I go to the doctor".

8छ) चीजों ... ब्योरे इस कागजज में पता लीखिए। Chiizon ... byore is kaagaz men

pataa likkhiye - "Please write the description $\boldsymbol{o f}$ things on this paper!"

8 झ) मोहन कैसे काम ... जाता है? Mohan keise kaam ... jaataa hei? - "Which job does Mohan go $\underline{\text { to }}$ ?"

8क) इस दुकान ... अच्छे जूते मिलते हैं। Is dukaan ... achchhe juute milte hein"There are very nice shoes $\underline{i n}$ this shop".

8ट) गीता खिडकी ... देख रही है। Giitaa khirkii ... dekh rahii hei - "Geeta is looking out from the window".

8ग) माताजी सीता ... सिर्फ़ चाय बनाती हैं। Maataajii Sitaa ... sirf chaay banaatii hein - "Mother makes only tea for Seeta".

8ज) आज से शुत्रवार ... हमारा एक बहुत अच्छा कमरा ख़ाली है। Aaj se shukravaar ... hamaaraa ek bahut achchhaa kamraa haalii hei - "The best our room is free from today $\underline{\text { till }}$ Friday". 
9घ) तुम हमेशा हम ... पैसा माँगते हो। Tum hameshaa ham ... peisaa maangte ho - "You always ask for money from us".

9ख) खाली प्लेट मेज़ ... रखिए। Haalii plet mez ... rakhive! - "Please take the empty plate on the table!".

9झ) वह स्कूल ... बहुत ध्यान से पढता है। Vah skuul ... bahut dhyaan se parhtaa $h e i-$ "He studies at school very zealously".

9ट) वह अपने देश ... लौटता है। Vah apne desh ... laotta hei - "He returns to his country".

9ज) रावण ... दो चाबियाँ हैं। Raavan ...do chaabiyaan hein - "Ravan has two keys".

9ग) आज सुरेन्द्र ... पत्र मिला। Aaj Surendra ... patra milaa - "The letter $\underline{\text { of }}$ Surendra has come today".

9छ) आज ... उस ने अपनी पुरानी गाड़ी चलाया। Aaj ... usne apnii puraanii gaarii chalaayaai - "He drove his old car till today".

9क) मेरे कमरों ... तीन काफ़ी हवादार हैं। Mere kamron ...tiin kaafii havadaar hein - "Three rooms are enough ventilated among all my rooms".

9च) तुम किस के ... यह काम कर रहे हो? Tum kis ke ... yah kaam kar rahe ho?"Whom you are doing this work for?".

During the Hindi lessons teachers can also suggest to student another interesting game - "Find the vowels!" - based on studying, repeating and learning vocabulary by heart.

Here it is:

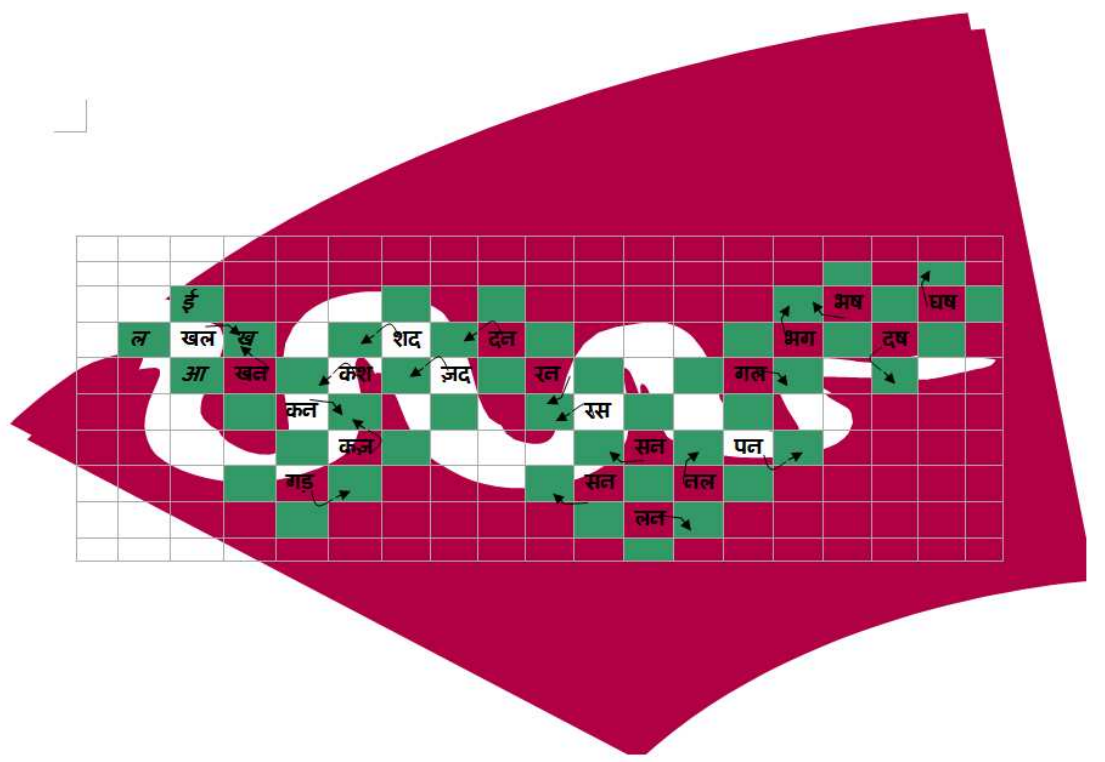


"Find the vowels!"

This snake is made of many codified words. Every one of them consists of 4 letters in Devanagary script. In the central square you see only consonants. Your task is to find out the vowels in order to create the whole word. After you got the word, write its letters beginning with the square, where the arrowhead points. The direction is also shown by the arrow clockwise or anticlockwise. For example:

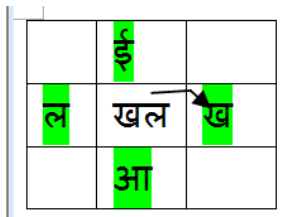

Here we got the word खाली khaalii - and we wrote it down beginning with the first letter ख $_{k h a}$ and putting it in the square, which was shown by the arrowhead. Its direction was clockwise - so other letters are written from left to right.

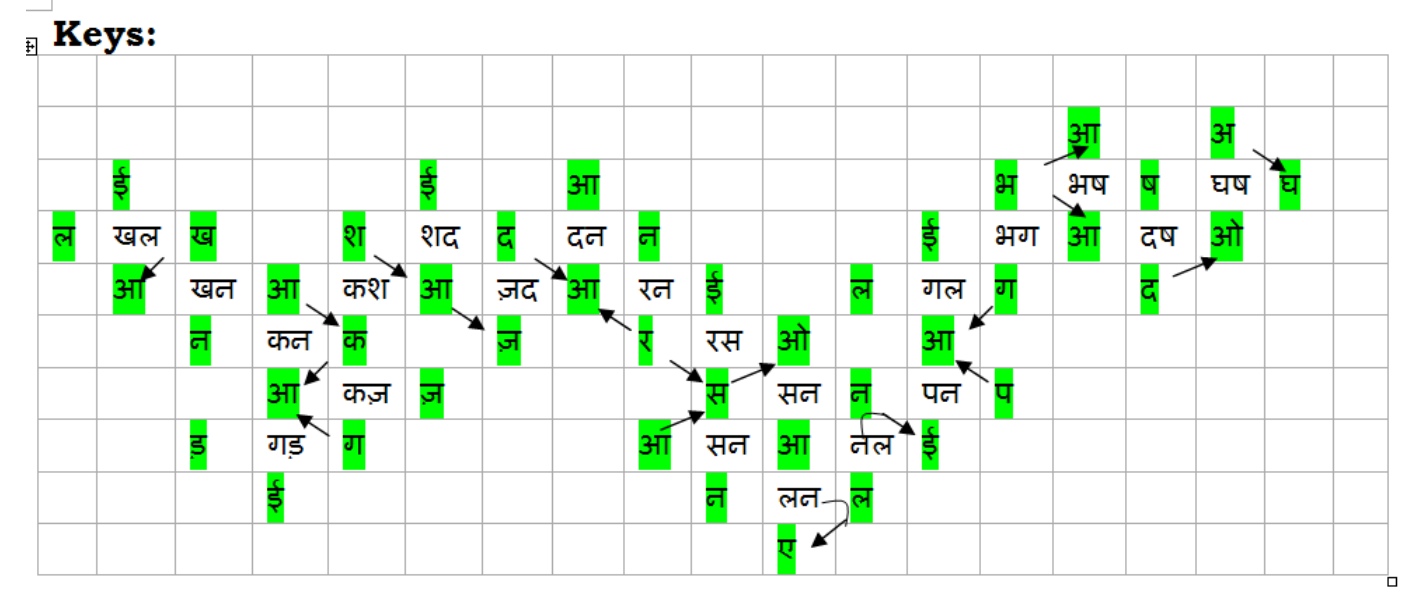

The vocabulary is one of the most important aspects in learning Hindi at the first stage. Successful memorization of new words enables any student to use them right in word-combinations and phrases. Thus the approaches to learning works on lessons of foreign languages must be various. 
Investigationes Linguisticae, vol. XX

\section{References}

Ting, T. 2009. Learning to Hypothesize with Confidence through Sudoku Game Play. English Teaching Forum (1), Vol. 47, 26-30.

Snell, R., Weightman, S. 1989. Teach Yourself Hindi. London: Hodder \& Stoughton. 